\title{
TEKNOLOGI EKSISTING USAHA TERNAK SAPI KELOMPOK TANI KARYA BERSAMA PADA PENDAMPINGAN PENGEMBANGAN KAWASAN PETERNAKAN KABUPATEN JAYAPURA
}

\author{
Batseba M.W. Tiro*, Petrus A. Beding, Ghalih P. Dominanto \\ Balai Pengkajian Teknologi Pertanian (BPTP) Papua \\ Jl. Yahim Sentani, Jayapura-Papua \\ *Corresponding author: batsebatiro68@gmail.com
}

\begin{abstract}
Jayapura is one of regencies in Papua which is designated as development of breeding area of beef cattle commodities. This study aims to present data and information about the profile of beef cattle farms in the Karya Bersama Farmer Group, Namblong district, Jayapura regency as the location for assisting the development of breeding area of beef cattle commodities. Data collection were conducted by survey and interview to 24 farmers at Kelompok Tani Karya Bersama that strengthened by Focus Group Discussion. The demonstration plot was carried out by introducing forage processing technology into silage and fermented straw as well as additional feed (bran) and observing the level of livestock reproduction. The results showed that the level of productivity of cattle is still relatively low, where calving interval is long (18-24 months), high S/C value (2 - 4), low birth weight (15-18 kg) and changes in body weight 0.1-0.2 kg/head/day. However, the assistance of technology can improve the productivity of cattle.
\end{abstract}

Keywords: assistance, development, technology, beef cattle, productivity

\begin{abstract}
Abstrak: Kabupaten Jayapura merupakan salah satu kabupaten di Papua yang ditetapkan sebagai pengembangan kawasan peternakan komoditas sapi potong. Kajian ini bertujuan untuk menyajikan data dan informasi mengenai profil usaha ternak sapi sapi potong pada kelompok tani Karya Bersama, Distrik Namblong, Kabupaten Jayapura sebagai lokasi pendampingan pengembangan kawasan peternakan komoditas sapi potong. Metode pengumpulan data dilakukan melalui survei dan wawancara langsung menggunakan kuisioner semi-struktur terhadap 24 responden peternak pada kelompok tani Karya Bersama dan dipertajam dengan Focus Group Discussion (FGD). Kegiatan demplot dilakukan dengan mengintroduksi teknologi pengolahan hijauan menjadi silase dan jerami fermentasi serta pakan tambahan (dedak) dan dilakukan pengamatan terhadap tingkat reproduksi ternak. Hasil kajian menunjukkan tingkat produktivitas ternak sapi masih tergolong rendah, dimana calving interval cukup panjang (18 - 24 bulan), nilai S/C tinggi $(2-4)$, bobot lahir rendah $(15-18 \mathrm{~kg})$ serta perubahan bobot badan induk 0,1-0,2 kg/ekor/hari. Namun dengan adanya pendampingan teknologi dapat memperbaiki kinerja produktivitas ternak sapi.
\end{abstract}

Kata kunci : pendampingan, pengembangan, teknologi, sapi potong, produktivitas

\section{PENDAHULUAN}

Pengembangan kawasan peternakan, khususnya bsapi potong memiliki sasaran utama nasional yakni meningkatkan populasi sapi potong menjadi 14,2 juta ekor pada tahun 2014 dengan rata-rata pertumbuhan sebesar $12,48 \%$, meningkatnya produksi daging dalam negeri sebesar 420,3 ribu ton pada tahun 2014 atau meningkat $10,4 \%$ setiap tahunnya (Permentan, 2010). Saat ini, pengembangan ternak sapi potong di pulau Jawa sudah semakin sulit karena daya dukung lahan yang terbatas. Konversi lahan yang cukup tinggi 
menyebabkan daerah pertanian termasuk peternakan di dalamnya semakin menyusut, walaupun daerah tersebut menyumbang $45 \%$ dari kebutuhan daging sapi dalam negeri. Sebaliknya, daerah luar pulau Jawa seperti Indonesia bagian timur yang cukup luas hanya menyumbang $16 \%$ dari kebutuhan daging sapi (Mersyah, 2005). Menurut Bamualim et al. (2008) potensi pengembangan sapi potong di wilayah tersebut masih sangat terbuka dan berpeluang untuk Indonesia Timur memiliki lahan yang cukup luas dan keragaman sumber pakan sehingga berpotensi untuk pengembangan ternak sapi potong.

Kabupaten Jayapura merupakan salah satu kabupaten di Papua yang ditetapkan sebagai pengembangan kawasan peternakan komoditas sapi potong selain Kabupaten Merauke, Nabire dan Keerom. Populasi sapi potong di Kabupaten Jayapura pada tahun 2016 sebesar 14.562 ekor dan meningkat pada tahun 2017 menjadi 14.825 (BPS Provinsi Papua, 2017). Peningkatan populasi sapi potong ini relatif kecil $(1,81 \%)$ dikarenakan sistem pemeliharaan ternak yang masih bersifat tradisional, dimana hanya dilepas dan pakan masih tergantung pada ketersediaan alam tentunya akan berpengaruh pada produktivitas ternak yang dihasilkan. Selain itu peternak belum menguasai teknologi pakan secara tepat sehingga sumber pakan belum dimanfaatkan secara optimal untuk mendukung pertumbuhan ternak.

Langkah-langkah strategis seperti perbaikan sistem pemeliharaan dengan jalan menggiatkan usaha penggemukan dan perbibitan yang dikelola oleh masyarakat berskala pengembangan kawasan pada wilayah sentra. Untuk mendukung hal tersebut perlu adanya upaya yang dilakukan dalam meningkatkan populasi dan produksi ternak antara lain melakukan pendampingan teknologi di tingkat petani dengan memanfaatkan sumberdaya lokal baik ternak, lahan, sumber pakan maupun peningkatan sumberdaya manusia dan infrastruktur sebagai penunjang.

Penelitian ini bertujuan untuk menyajikan data dan informasi mengenai teknologi eksisting usaha ternak sapi potong pada kelompok tani Karya Bersama, Distrik Namlong, Kabupaten Jayapura.

\section{METODE PENELITIAN}

Penelitian ini dilaksanakan pada bulan MeiNovember 2017, pada kelompok tani Karya Bersama di Kampung Karya Bumi, Distrik Namblong Kabupaten Jayapura dan merupakan bagian dari kegiatan pendampingan pengembangan kawasan peternakan komoditas sapi potong di Papua. Pemilihan lokasi kegiatan dilakukan secara sengaja (purposive) berdasarkan pertimbangan lokasi ini merupakan sentra pengembangan sapi potong yang telah ditetapkan oleh pemerintah daerah. Penentuan lokasi dilakukan setelah berkoordinasi dengan instansi terkait.

Penentuan responden pada penelitian ini dilakukan secara sengaja (purposive sampling), dimana responden yang dipilih adalah seluruh anggota kelompok tani Karya Bersama. Jumlah responden petani/peternak sebagai sampel yang digunakan dalam kajian ini sebanyak 24 orang petani sebagai responden.

Metode pengumpulan data dilakukan melalui survei dan wawancara langsung menggunakan kuesioner semi-struktur terhadap 24 responden peternak pada kelompok tani Karya Bersama dan dipertajam dengan Focus Group Discussion (FGD). Data yang dikumpulkan yaitu data sekunder meliputi keadaan umum wilayah dan populasi ternak babi yang diperoleh dari Dinas/Instansi terkait, sedangkan data primer meliputi struktur organisasi kelompok, jumlah anggota, jumlah ternak, sistem pemeliharaan, dan perkawinan ternak, tingkat mortalitas sistem pemeliharaan dan kesehatan ternak. Data yang telah terkumpul dilakukan tabulasi data dan analisis data dengan menggunakan analisis deskriptif kualitatif dan kuantitatif.

\section{HASIL DAN PEMBAHASAN}

\section{Gambaran umum lokasi penelitian}

Kabupaten Jayapura memiliki luas 17.514.000 $\mathrm{km}^{2}$ yang terdiri dari 19 distrik, 5 kelurahan dan 139 kampung. Distrik Kaureh merupakan wilayah dengan luasan terbesar yakni $4.357 .977 \mathrm{~km}^{2}(24,88 \%)$ sedangkan distrik Sentani Barat merupakan wilayah dengan luasan terkecil yakni $129.125 \mathrm{~km}^{2}(0,74 \%)$ dari total luas wilayah di kabupaten Jayapura. Kabupaten Jayapura merupakan bagian dari 
zona tropis lembab dengan iklim yang cenderung panas, basah (lembab) dengan curah hujan yang bervariasi antara satu tempat dengan tempat lainnya.

Salah satu tujuan Dinas Pertanian kabupaten Jayapura dalam strategi dan arah kebijakan pembangunan pertanian tahun 20122017 adalah meningkatkan pemanfaatan dan pelestarian potensi komoditi spesifik lokasi dengan sasarannya adalah meningkatnya kawasan sagu budidaya produktif dan pengembangan pangan spesifik lokasi. Luas areal pertanaman sagu di kabupaten Jayapura adalah 347 ha atau $4,95 \%$ dari total luas areal pertanaman sagu di Papua. Sedangkan kebijakan sub sektor peternakan adalah peningkatan produksi daging dan telur yang berdasarkan kesesuaian pengembangan ternak. Pemenuhan kebutuhan daging dan telur di kabupaten Jayapura bersumber dari produksi lokal dan disuplai dari produksi daging antar pulau untuk memenuhi permintaan konsumen yang semakin meningkat. Sampai saat ini produksi daging dan telur di kabupaten Jayapura masih belum mencukupi oleh karena tingginya permintaan daging antar kota di Papua juga disuplai dari kabupaten Jayapura. Upaya untuk meningkatkan produksi daging di Jayapura melalui penyebaran bibit/bakalan dan penggemukan sapi potong kepada masyarakat serta upaya peningkatan pelayanan kesehatan hewan dan perlindungan kesehatan bagi masyarakat veteriner.

Tabel 1. Populasi Ternak di Kabupaten Jayapura Tahun 2017

\begin{tabular}{lccc}
\hline \multirow{2}{*}{ Jenis ternak } & \multicolumn{2}{c}{ Populasi (ekor) } & Peningkatan \\
\cline { 2 - 3 } & 2016 & 2017 & $(\%)$ \\
\hline Sapi potong & 14.562 & 14.825 & 1,81 \\
Kerbau & 124 & 96 & $-22,58$ \\
Kambing & 4.018 & 4.653 & 15,80 \\
Babi & 14.724 & 15.687 & 6,54 \\
Ayam buras & 46.463 & 48.532 & 4,45 \\
\hline Sumber : & Laporan Tahunan Dinas & Peternakan \\
& \multicolumn{3}{c}{ Provinsi Papua, 2017 }
\end{tabular}

Upaya ini tentunya harus didukung dengan ketersediaan pakan baik kuantitas maupun kualitasnya. Pengamatan di lapangan, sebagian besar sistem pemeliharaan ternak sapi pada masyarakat lokal masih bersifat ekstensif tanpa ada campur tangan peternak. Pada pagi hari ternak dilepas untuk mencari pakan dan pada sore hari ternak akan kembali ke kandang dalam bentuk range tanpa ada pakan tambahan. Data populasi ternak di Kabupaten Jayapura tahun 2016 dan 2017 seperti pada Tabel 1.

Terlihat bahwa untuk ternak besar, populasi sapi potong di Kabupaten Jayapura lebih besar dibanding ternak lainnya, ini menunjukkan bahwa sapi potong berpotensi cukup besar untuk dikembangkan. Hal ini didukung juga oleh ketersediaan hijauan pakan, dimana kondisi Jayapura perbedaan musimnya kurang jelas sehingga hijauan alam maupun hijauan yang dibudidayakan cukup tersedia dibanding di Kabupaten Merauke yang musim kemaraunya lebih lama dibanding musim hujan. Potensi yang ada ini perlu dikelola baik dengan memanfaatkan sumberdaya pakan lokal yang ada selain hijauan sehingga populasi sapi potong di daerah ini dapat ditingkatkan.

\section{Profil usaha ternak}

Kelompok tani Karya Bersama dibentuk sejak tahun 2012 yang beranggotakan 24 orang. Jenis ternak sapi potong yang dipelihara adalah sapi Bali yang merupakan bantuan dari program Bansos melalui Dinas Peternakan. Pada awalnya kelompok mendapat bantuan ternak sapi Bali sebanyak 48 ekor, yang terdiri dari betina dewasa 44 ekor dan jantan dewasa 4 ekor. Kondisi saat ini terjadi peningkatan populasi ternak sapi menjadi 73 ekor yang terdiri dari betina dewasa 43 ekor, pedet betina 15 ekor dan pedet jantan 15 ekor dengan skala pemeliharaan yang relatif rendah yakni rata-rata kepemilikan 2-3 ekor/KK.

Pada awalnya ternak sapi dipelihara dalam satu kandang komunal, namun karena kondisi lokasi kandang yang kurang baik sehingga pada saat hujan kandang tergenang air. Kondisi seperti ini menyebabkan ternak banyak yang stress dan mati, sehingga peternak menarik kembali ternaknya dan dipelihara di pekarangan rumah dan sebagian di dalam range yang dibuat masing-masing peternak. Kandang komunal milik kelompok yang merupakan bantuan Dinas Peternakan untuk kondisi sekarang dibiarkan kosong dan tidak dimanfaatkan oleh peternak.

\section{Sistem pemeliharaan}

Sistem pemeliharaannya masih secara semi intensif, ternak dipelihara di pekarangan yang 
cukup luas dan dibuat range ada juga sebagian yang rangenya berada jauh dari tempat tinggal dekat areal persawahan. Pemberian pakan dilakukan hanya sekali yaitu pada sore hari dengan jumlah pemberian rata-rata 5-10 $\mathrm{kg} / \mathrm{ekor}$. Usaha tani yang dominan adalah padi sawah sehingga usaha ternak hanya sebagai sampingan, namun justru sumbangan pendapatan terbesar berasal dari ternak. Ternak sapi berfungsi sebagai tabungan yang sewaktuwaktu dapat dijual. Pakan yang diberikan hanya mengandalkan ketersediaan rumput alam dengan tambahan rumput gajah yang ditanam di areal pematang sawah, namun dalam pemberiannya belum sesuai dengan kebutuhan ternak. Sistem pemeliharaan ternak sapi oleh peternak pada kelompok tani Karya Bersama disajikan pada Tabel 2.

Tabel 2. Sistem Pemeliharaan Ternak Sapi pada Kelompok Tani Karya Bersama

\begin{tabular}{lcc}
\hline U r a i a n & $\begin{array}{r}\text { Jumlah } \\
\text { (orang) }\end{array}$ & $\begin{array}{c}\text { Persentase } \\
(\%)\end{array}$ \\
\hline $\begin{array}{l}\text { Dilepas siang malam } \\
\text { dalam range }\end{array}$ & 12 & 50,0 \\
$\begin{array}{l}\text { Diikat di kebun/samping } \\
\text { rumah }\end{array}$ & 10 & 41,7 \\
$\begin{array}{l}\text { Dikandangkan sepanjang } \\
\text { hari }\end{array}$ & 2 & 8,3 \\
\hline
\end{tabular}

Data pada Tabel 2 menunjukkan bahwa sistem pemeliharaan yang dilakukan sebagian besar $(50 \%)$ dilepas siang malam dalam range, $41,7 \%$ diikat di kebun atau di samping rumah dan hanya $8,3 \%$ yang ternaknya dikandangkan sepanjang hari. Hasil kajian yang dilakukan di Kabupaten Keerom (Tiro et al., 2016), sistem pemeliharaan ternak sapi sebagian besar $(66,67 \%)$ ternaknya diikat di kebun atau samping rumah, $28,57 \%$ ternaknya dilepas di areal kebun kelapa sawit tanpa ada campur tangan peternak dan sebagian kecil (4,76\%) peternak sudah mengandangkan ternaknnya. Sedangkan sistem pemeliharaan pada kelompok tani Sejahtera Kabupaten Nabire, seperti yang dilaporkan Usman et al. (2016), pemeliharaan ternak dengan sistem ikat pindah (70\%), dilepas siang malam $(20 \%)$ dan yang dikandangkan $(4,7 \%)$. Terlihat bahwa sistem pemeliharaan ternak sapi pada ketiga lokasi yakni di Kabupaten Jayapura, Keerom dan Nabire umumnya sama hanya sebagian kecil peternak yang sudah mengandangkan ternaknya.

Sistem pemeliharaan ini tentunya akan sangat berpengaruh terhadap produksi ternak. Sariubang et al. (2002) menyatakan bahwa kurangnya ketersediaan pakan merupakan salah satu sebab terjadinya penurunan kualitas dan kuantitas ternak sapi potong. ternak sapi yang dipelihara di padangan, pada musim hujan suplai energi, protein dan mineral melebihi kebutuhan hidup pokok ternak sehingga terjadi pertumbuhan ternak yang signifikan (Bamualim dan Wirdahayati, 2002).

Di lain pihak terdapat sumber pakan alternatif berupa jerami padi yang berlimpah dan limbah penggilingan padi berupa dedak tapi belum dimanfaatkan oleh peternak. Menurut peternak, ternak sapi tidak mau mengkonsumsi jerami padi dan dedak, sehingga jerami padi dibiarkan begitu saja setelah panen sedangkan dedak lebih banyak dijual (untuk ternak ayam dan babi) daripada digunakan sebagai pakan untuk ternaknya sendiri. Ada juga sebagian peternak (20\%) yang memberikan dedak untuk ternak sapi hanya sekitar $1 \mathrm{~kg} / \mathrm{hari}$ dan diberikan hanya pada saat panen. Dedak yang ada lebih banyak dijual daripada diberikan ke ternaknya sendiri dengan harga per karung $50 \mathrm{~kg}$ Rp 160.000 170.000, sehingga harga per kg dedak berkisar Rp. 3.200 - 3.400. Bagi ternak yang dipelihara dalam range di pekarangan, air minum disediakan, namun ternak yang dipelihara dalam range yang jauh dari tempat tinggal air minum untuk ternak tidak disediakan, ternak akan mencari sendiri air minum di sekitar range.

Selama ini peternak belum memperoleh informasi maupun pelatihan untuk pemanfaatan jerami padi sebagai sumber pakan serat untuk ternak, sehingga ada anggapan bahwa jerami padi tidak layak untuk diberikan kepada ternak. Di lain pihak teknologi untuk meningkatkan kualitas nutrisi jerami padi sudah lama diperkenalkan, sehingga peternak meminta untuk bisa mengenalkan teknologi pengolahan jerami padi menjadi pakan ternak ke kelompok ternak yang ada.

\section{Sistem perkawinan}

Sistem perkawinan yang dilakukan adalah kawin alam (50\%) dan menggunakan 
inseminasi buatan (IB) juga 50\%. Menurut pengakuan peternak, mereka lebih menyukai sistem kawin alam karena tingkat keberhasilannya lebih tinggi dibanding IB. Pada sistem perkawinan menggunakan IB, nilai S/C nya di atas 2 bahkan ada yang S/C nya sampai 4 sedangkan nilai $\mathrm{S} / \mathrm{C}$ yang ideal adalah 1 (Diwyanto, 2015). Nilai S/C yang tinggi ini diduga karena deteksi estrusnya yang kurang tepat atau kualitas semennya yang kurang baik. Sistem pemeliharaan yang dilepas akan menyulitkan peternak untuk mendeteksi ternak yang sedang estrus sehingga sewaktu di IB kemungkinan waktu estrusnya sudah lewat yang akan berpengaruh terhadap tingkat keberhasilan dari IB. Keberhasilan S/C selain dipengaruhi oleh ketepatan waktu dalam pelaksanaan inseminasi, juga dipengaruhi oleh kualitas semen yang secara langsung dipengaruhi oleh proses penanganan dan penyimpanannya. Proses penyimpanan semen mempunyai pengaruh besar terhadap daya hidup spermatozoa dalam straw. Toelihere (1981), menyatakan bahwa semua usaha untuk mensukseskan pelaksanaan inseminasi buatan dengan penampungan, perlakuan dan pengolahan semen secara sempurna akan siasia apabila fase terakhir prosedur inseminasi tidak dilaksanakan sebagaimana mestinya. Pemakaian yang tepat dari semen fertil pada waktu inseminasi adalah esensial untuk kesuburan yang tinggi. Hal ini memerlukan deteksi dan pelaporan estrus yang tepat sehingga inseminasi dapat dilakukan secara cermat oleh tenaga terampil, dan hewan betina yang sehat dalam kondisi reproduksi yang optimal sangatlah penting.

Nilai S/C yang tinggi secara tidak langsung akan berpengaruh terhadap atau calving interval. Di tingkat peternak, jarak beranak induk sapi potong mencapai 18-24 bulan dengan calving rate 40-50\%. Pada kondisi yang ideal dengan manajemen pemeliharaan yang baik, jarak beranak dapat diperpendek menjadi 12-14 bulan dengan calving rate 70-90\% (Diwyanto, 2015). Jarak beranak dipengaruhi oleh post partum mating, lama bunting dan S/C, dimana jarak beranak 12 bulan adalah waktu yang paling baik secara ekonomis. Namun menurut Diwyanto et al. (2009), panjangnya jarak beranak lebih banyak dipengaruhi oleh anestrus post partum dan days open, walaupun secara umum terdapat kecenderungan S/C yang tinggi akan menyebabkan jarak beranak menjadi panjang. Jarak beranak yang panjang merupakan kendala inefisiensi produktivitas sapi potong di Indonesia (Winugroho, 2002), yang penyebab utamanya adalah keterlambatan estrus pertama pasca beranak.

\section{Mortalitas}

Pada awal pemeliharaan, saat ternak dipelihara di kandang komunal tingkat kematian pedet sangat tinggi yakni mencapai $70 \%$. Hal ini disebabkan kondisi induk yang stress dan pakan yang dikonsumsi selama bunting dan menyusui tidak mencukupi kebutuhan induk, sehingga anak yang dilahirkan kondisinya lemah dan bobot lahirnya yang rendah (8-10 $\mathrm{kg}$ ) berakibat daya tahan tubuhnya menurun. Selain itu, menurut peternak, ternak sapi yang dipelihara umumnya menderita cacingan sehingga kondisi ternaknya agak kurus. Kenyataan di lapangan, terlihat bahwa pemberian pakan yang seadanya saja dimana hijauan dibuang begitu saja di dalam range (tidak ada tempat pakan yang disediakan) memungkinkan terjadi penyebaran penyakit cacingan ini dengan cepat. Pengobatan sudah dilakukan oleh petugas Keswan namun belum dapat menuntaskan permasalahan yang ada.

\section{Kelembagaan kelompok peternak}

Jumlah anggota kelompok tani sebanyak 24 orang dengan struktur organisasi terdiri dari Ketua, Sekretaris dan Bendahara. Kelompok tani ini dilengkapi dengan kelengkapan administrasi berupa buku tamu dan buku pencatatan kelahiran. Namun demikian pertemuan rutin tidak pernah dilaksanakan. Tidak pernah adanya pertemuan rutin salah satu penyebabnya karena kesibukan dari ketua kelompok yang jarang berada di tempat. Ketua kelompok adalah seorang tenaga inseminator dan pada saat ini tergabung dalam Tim gertak berahi yang merupakan program dari Dirjen PKH Kementerian Pertanian.

Kelompok peternak ini juga merupakan binaan dari Dinas Perkebunan dan Peternakan Kabupaten Jayapura sehingga usaha ternak berpotensi untuk terus dikembangkan dalam upaya pengembangan sapi potong kedepannya. Pendampingan dilakukan secara keberlanjutan 
dengan inovasi teknologi penyediaan pakan dan perkandangan, ditunjang juga oleh peran ketua kelompok sebagai tenaga inseminator sehingga pengembangan usaha ternak sapi potong terus berkembang.

\section{Introduksi teknologi dalam pendampingan kawasan sapi potong}

Pada kegiatan pendampingan pengembangan kawasan peternakan sapi potong ini juga diterapkan beberapa jenis inovasi paket teknologi Badan Litbang Pertanian seperti pada Tabel 3.

Berdasarkan kondisi eksisting, dengan permasalahan yang ada yakni terbatasnya hijauan pakan dan dengan potensi yang ada berupa jerami padi yang belum dimanfaatkan maka inovasi teknologi yang didemonstrasikan pada kegiatan pendampingan pengembangan kawasan ternak sapi potong adalah teknologi pembuatan fermentasi jerami padi. Selain demonstrasi inovasi teknologi tersebut juga diintroduksi model bank pakan model Balitbangtan sehingga jerami padi akan disimpan dalam bank pakan dan ternak akan merenggut atau mengkonsumsi langsung jerami padi yang ada dalam bank pakan. Model bank pakan ini akan mengurangi tenaga kerja peternak dalam hal penyediaan pakan untuk ternaknya.

Seiring berjalannya pendampingan, terlihat di lapangan bahwa hijauan cukup berlimpah pada saat musim hujan dan dibiarkan sampai tua dan tidak dipanen. Sehingga untuk mengatasi masalah tersebut disepakati untuk dibuat bimbingan teknis pembuatan silase hijauan sehingga pada saat hijauan berlimpah bisa disimpan dalam waktu yang lebih lama. Silase adalah pakan ternak yang berbahan dasar rumput atau jerami yang difermentasi selama beberapa minggu untuk meningkatkan daya simpan dan nilai nutrisi dari rumput segar. Pada bimbingan teknis ini rumput yang digunakan adalah rumput gajah (Pennisetum purpureum) sebagai bahan baku, dedak, gula merah sebagai pengganti molases, EM4 (efective microorganism) untuk mempercepat proses fermentasi, dan alat yang digunakan adalah kantong plastik sampah dan terpal. Proses pembuatan silase dimulai dengan mencacah rumput gajah yang masih segar dengan mesin Chopper sehingga berukuran $\pm 5 \mathrm{~cm}$. Hasil cacahan rumput gajah dihamparkan di atas terpal dan dipercik dengan larutan gula merah yang telah dicampurkan EM4 sambil dibolak balik agar cairan membasahi semua bagian hamparan. Setelah tercampur rata hamparan kembali ditaburi dengan dedak dan dihomogenkan kembali. Proses terakhir adalah memasukan potongan rumput gajah kedalam kantong plastik dan menekan tumpukannya agar kedap udara kemudian diikat kuat. Bungkusan rumput gajah tersebut disimpan ditempat kering dan terhindar dari sinar matahari langsung selama \pm 3 minggu. Ciri-ciri silase yang baik adalah berbau harum alkohol dan warnanya tidak hitam serta tidak berjamur.

Hasil pengamatan terhadap performa ternak sebelum dan sesudah pendampingan terlihat pada Tabel 4.

Tabel 3. Penerapan Inovasi Paket Teknologi pada Kelompok Tani Karya Bersama, Kampung Karya Bumi, Distrik Namlong, Kabupaten Jayapura.

\begin{tabular}{|c|c|c|c|}
\hline No. & Inovasi teknologi & Pola pendampingan & Tanpa pendampingan \\
\hline 1. & Kandang & $\begin{array}{l}\text { Kandang induk di dalam range }+ \text { tempat } \\
\text { makan dan minum }\end{array}$ & Dilepas \\
\hline 2. & Pakan & $\begin{array}{l}\text { Hijauan } 10 \% \text { BB (rumput gajah, rumput } \\
\text { lapangan, jerami segar, legum rambat) }+ \\
\text { dedak } 1 \% \text { BB + garam secukupnya }\end{array}$ & Hijauan $100 \%$ \\
\hline 3. & Sistem perkawinan & InKA/IB & InKA/IB \\
\hline 4. & $\begin{array}{l}\text { Budidaya tanaman } \\
\text { pakan ternak }\end{array}$ & Penanaman legume Indigofera $S p$. & - \\
\hline 5. & Pelatihan & $\begin{array}{ll}\text { - } & \text { Fermentasi jerami padi } \\
\text { - } & \text { Silase hijauan }\end{array}$ & $\begin{array}{ll}\text { - } & \text { Fermentasi jerami padi } \\
\text { - } & \text { Silase hijauan }\end{array}$ \\
\hline
\end{tabular}


Tabel 4. Efisiensi Reproduksi Induk Sapi Potong Sebelum dan Sesudah Pendampingan pada Kelompok Tani Karya Bersama, Kabupaten Jayapura.

\begin{tabular}{lcc}
\hline \multicolumn{1}{c}{ Uraian } & $\begin{array}{c}\text { Sebelum } \\
\text { pendampingan }\end{array}$ & $\begin{array}{c}\text { Sesudah } \\
\text { pendampingan }\end{array}$ \\
\hline $\begin{array}{l}\text { SKT induk } \\
\text { Calving } \\
\text { interval } \\
\text { (bulan) }\end{array}$ & $2-3$ & $3-3,5$ \\
S/C & $18-24$ & $13-14$ \\
$\begin{array}{l}\text { Berat lahir } \\
\text { (kg) }\end{array}$ & $2-4$ & $<2$ \\
$\begin{array}{l}\text { PBB induk } \\
\text { (kg) }\end{array}$ & $0,1-0,2$ & $0,2-0,3$ \\
\hline $\begin{array}{l}\text { Keterangan: } \\
\text { SKT : Skor Kondisi Tubuh; S/C } \\
\text { conception }\end{array}$ & & Service per
\end{tabular}

Perbaikan pakan pada induk dengan penambahan dedak $1 \%$ BB dapat memperbaiki SKT induk menjadi 3 - 3,5 yang merupakan SKT optimun untuk dapat bereproduksi dengan baik, memperpendek calving interval menjadi 13 - 14 bulan dan meningkatkan bobot lahir pedet dari $15-18 \mathrm{~kg}$ menjadi $20-25 \mathrm{~kg}$ serta dapat memperbaiki induk dimana perubahan bobot badan (PBB) induk tanpa dan dengan pendampingan adalah $0,1-0,2 \mathrm{~kg} / \mathrm{ekor} / \mathrm{hari}$ dan 0,2- 0,3 kg/ekor/hari.

PBB induk sapi pada pola petani tanpa pendampingan relatif rendah, namun dengan adanya pendampingan dengan memanfaatkan pakan lokal yang ada sebagai pakan tambahan dapat meningkatkan PBB induk. Hasil penelitian Hasan et al. (1990) diperolah pertambahan bobot badan sapi Bali yang dipelihara di padang penggembalaan rendah yakni berkisar $0,05-0,10 \mathrm{~kg} / \mathrm{ekor} / \mathrm{hari}$, sedangkan menurut Gunawan et al. (1998), sapi Bali yang dipelihara secara tradisional dengan pakan hijauan berupa rumput-rumputan dan hijauan inkonvensional memberikan pertambahan bobot badan $0,1-0,2$ $\mathrm{kg} / \mathrm{ekor} / \mathrm{hari}$. Hal ini terkait juga dengan pakan yang dikonsumsi ternak belum mencukupi kebutuhan ternak untuk berproduksi dengan baik. Retnani et al. (2010), menyatakan bahwa pakan merupakan faktor penentu produktivitas ternak, sehingga ketersediaan pakan yang berkualitas baik merupakan persyaratan untuk pengembangan ternak di suatu wilayah. Pakan yang diberikan pada ternak sapi penggemukan ditujukan untuk mencapai pertambahan bobot badan yang setinggi-tingginya dalam waktu relatif singkat. Untuk itu pemberian pakan hendaknya disesuaikan dengan kebutuhan baik dari segi kuantitas maupun kualitasnya.

\section{KESIMPULAN}

Sistem pemeliharaan ternak sapi potong pada kelompok tani Karya Bumi sebagian besar dilepas dalam range dengan pemberian pakan hijauan hanya 1 kali/hari, yang berpengaruh pada tingkat produktivitas ternak (panjangnya calving interval, nilai $\mathrm{S} / \mathrm{C}$ tinggi serta bobot lahir yang rendah). Pendampingan teknologi melalui demonstrasi teknologi dan pemanfaatan pakan lokal berpengaruh positif terhadap produktivitas ternak, terlihat dari calving interval menjadi lebih pendek, nilai S/C menjadi rendah dan bobot lahir anak lebih tinggi serta memperbaiki bobot badan induk sapi.

\section{DAFTAR PUSTAKA}

Badan Pusat Statistik Provinsi Papua. 2017. Papua dalam Angka. Papua: BPS Provinsi Papua.

Bamualim, A.M., dan Wirdahayati, R.B. 2002. Peternakan di Lahan Kering Nusa Tenggara. Nusa Tenggara Timur: Balai Pengkajian Teknologi Pertanian Nusa Tenggara Timur, 1-120.

Bamualim, A.M., Trisnamurti, B., dan Thalib, C. 2008. Arah Penelitian Pengembangan Sapi Potong di Indonesia (hal. 4-12) dalam Amar, A.L., Husain, M.H., Kasim, K., Marsetyo, Duma, Y., Rusyantono, Y., Rusdin, Damry, dan Sundu, B (Ed). Pengembangan Sapi Potong untuk Mendukung Percepatan Pencapaian Swasembada Daging Sapi 2008-2010. Prosiding Seminar Nasional, Palu, 24 November 2008. Kerja Sama antara Universitas Tadulako, Sub Dinas Peternakan dan Dinas Pertanian Perkebunan dan Peternakan Sulawesi Tengah.

Dinas Peternakan dan Kesehatan Hewan Papua. 2017. Laporan Tahunan Dinas Peternakan Provinsi Papua. Papua: 
Dinas Peternakan dan Kesehatan Hewan Papua.

Diwyanto, K., Inouno, I., dan Priyanti A. 2009. Dampak Crossbreeding Terhadap Kinerja Reproduksi Sapi Potong di Indonesia. Pusat Penelitian dan Pengembangan Peternakan. Jakarta: Badan Penelitian dan Pengembangan Pertanian.

Diwyanto, K. 2015. Parameter Terukur Manajemen Perkawinan/Reproduksi Sapi dalam Pendampingan Integrasi TanamanTernak. Koordinasi Pendampingan Integrasi Tanaman-Ternak Tanggal 25 Maret 2015. Bogor: Puslitbangnak Bogor.

Gunawan, D. P., dan Affandy, L. 1998. Sapi Bali: Potensi, Produktivitas, dan Nilai Ekonomi. Yogyakarta: Kanisius.

Hasan, A., A. Ako dan Sudirman. 1990. Fattening by Feedlot and Pasture Feedlot At Body Weight Gain of Bali Cattle. Prosiding Seminar Nasional Sapi Bali. Bali: Fakultas Peternakan Udayana.

Mersyah, R. 2005. Desain Sistem Budidaya Sapi Potong Berkelanjutan Untuk Mendukung Pelaksanaan Otonomi Daerah di Kabupaten Bengkulu Selatan. Disertasi. Sekolah Pascasarjana Institut Pertanian Bogor.

Badan Penelitian dan Pengembangan Pertanian Kementerian Pertanian. 2010. Peraturan Menteri Pertanian: Pedoman Umum Perencanaan Penelitian dan Pengembangan Pertanian. Jakarta: Badan Penelitian dan Pengembangan Pertanian Kementerian Pertanian.
Retnani, Y., Kamesworo, S., Khotidjah, L., dan Saenab, A. 2010. Pemanfaatan Wafer Limbah Sayuran Pasar Untuk Ternak Domba. Prosiding Seminar Nasional Teknologi Peternakan dan Veteriner, 503-510. Pusat Penelitian dan Pengembangan Peternakan.

Sariubang, M., Ella, A., Nurhayu, A., Pasambe, D. 2002. Kajian Integrasi Usaha Ternak Sapi Potong Dalam Sistem Usaha Pertanian di Sulawesi Selatan. Wartazoa, $12(1), 24-28$.

Tiro, B.M.W., Usman, dan Nurawaliah, S. 2016. Karakteristik dan Sistem Perkawinan Sapi Potong di Kabupaten Keerom, Papua. (Studi Kasus Peternak Sapi Potong di Distrik Arso Kabupaten Keerom). Prosiding Seminar Nasional Inovasi Teknologi Pertanian Spesifik Lokasi. Balai Besar Pengkajian dan Pengembangan Teknologi Pertanian, Badan Litbang Pertanian.

Toelihere, M.R. 1981. Inseminasi Buatan Pada Ternak. Bandung: Angkasa.

Usman, B.M.W. Tiro, S. T., dan Bustami. 2016. Keragaan Usahaternak Sapi Potong Pada Kelompok Tani Sejahtera di Kabupaten Nabire, Papua. Prosiding Seminar Nasional Membangun Pertanian Modern dan Inovatif Berkelanjutan dalam Rangka Mendukung MEA, 1127 1133.

Winugroho, M. 2002. Strategi Pemberian Pakan Tambahan untuk Memperbaiki Efisiensi Reproduksi Induk Sapi. Jurnal Litbang Pertanian, 21(1), 19 - 23. 